\title{
Study of the Potential Sharing of the Electricity Subsidy by Regional Government
}

\author{
Joko Tri Haryanto \\ Center for Climate Change Financing and Multilateral Policy, Fiscal Policy Agency, \\ Ministry of Finance of Republic of Indonesia, Indonesia \\ Djohar78@gmail.com
}

\begin{abstract}
The electricity sector has a very important role as a source of energy that is vital for everyday life, industrial activities and other commercial activities. To keep electricity prices remain affordable to the public, government allocated electricity subsidy in the APBN. Unfortunately, every year electricity subsidy is more swollen. Therefore needs to consider funding the electricity subsidy sharing mechanism with regional governments. To support these mechanisms, necessary to study and trying to see the readiness level of funding in regional government and the division of authority. By using the methodology of mapping analysis, it can be concluded that the judicial authority of the electricity sector although it has been submitted to the region, but still the absolute authority of the Central Government. Based on the Regional Fiscal Capacity analysis, Jakarta Province, East Kalimantan Province, Papua Province of West and North Borneo are areas that deserve to be a top priority. By using the analysis of the development of regional economic growth from 2008 to 2012, the recommended area is the province of West Papua with an average economic growth, approximately $23.28 \%$ compared to Jakarta by $7.75 \%$ and by $5.08 \%$ in East Kalimantan.
\end{abstract}

Keywords: Electricity subsidy, APBN, Local government, Local fiscal capacity

\section{Introduction}

Based on the research Bappenas (2011), it stated that the electricity sector has a very important role in the process of development to enhance the society welfare. This need is inherent in all levels of society, especially the need for lighting for the fulfilment of daily activities need. Therefore the electric power has become a source of energy that is vital for the daily household life, industrial activities, especially small and medium enterprises (SMEs) as well as other commercial activities (Hadi, 2015). In other case, according to (Ahlborg, 2015) electricity is a unique energy carrier that is purposefully applied in almost all aspect of daily life among the richest segment of the world's population. It is also essential for the modern communications, industrial development and the build-up of public services such as streetlights, improved education and health care. And the most important thing from those aspect, the existing and future applications of electricity and other modern energy carriers will be instrumental to achieving many of the Sustainable Development Goals (SDGs) adopted in September 2015 by the member states of the United Nations. Unfortunately, most of the electricity generation activities are heavily dependent to the supply of fossil-based fuel. Even though, fossil-based fuel is categorized as non-renewable source of energy and its availability is keep decreasing over time. Therefore, the dependency over fossil-based fuel as the supply of electricity generation should be minimized to the optimal level, either from the demand side or from the development of alternative of power supply that has renewable characteristic (BKF, 2011).

The fulfilment of energy needs that depends on the fossil-based fuel basis is often disrupting the national energy supply, moreover if there is fossil-based fuel price hike in the international market. This condition is could decrease the power supply then as a result the electricity subsidy is increasing. It is worth to note that the crude oil reserve in this country nowadays is only last about $1.2 \%$ compare to the world's crude oil reserve (BKF, 2008). The high pressure of electricity fulfilment is often causing a problem, especially if there is power scarcity due to the high demand, which overwhelmed the actual power supply or the increasing fossil-based fuel prices in the international market, causing the actual power supply decreasing. If this condition recurring more frequently, the event of power scarcity or energy crisis will be more often encountered in Indonesia (Haryanto \& Wahyu, 2014). In the chart below, we can see historical data of the progress of demand and supply of electricity in Indonesia: 
Figure 1: The Progress of Electricity Demand and Supply in Indonesia (TWh)

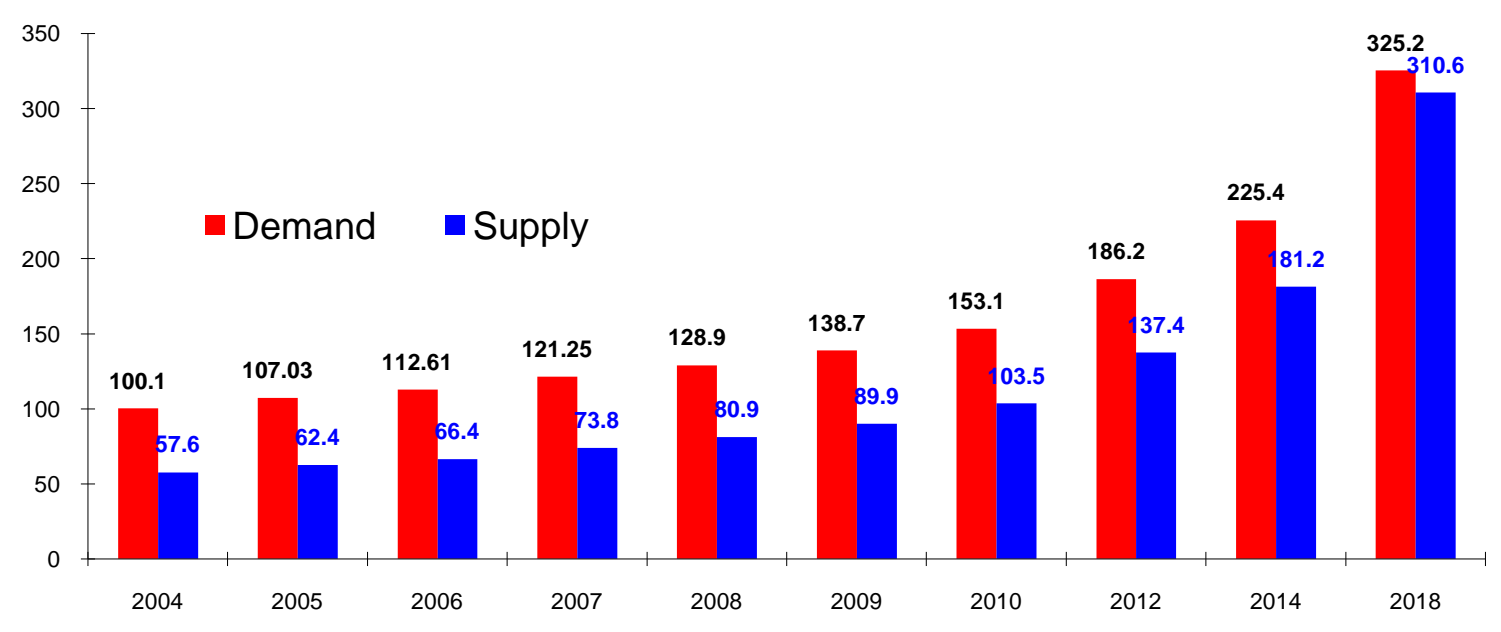

Source: PLN, 2014

Based on Figure 1, it can be analysed that from 2004 to 2018, the energy crisis has actually occurred when the actual electricity offer cannot follow the actual growth in electricity demand in Indonesia. It is reasonable, if we compare the high demand of electricity consumption that is proportional to the magnitude of the economic growth, In addition, the increase of the usage is happen in almost all sectors, whether industrial, household, or public and business sectors. In order to reduce the burden of the electricity deficit, some of the efforts that must be done are to look for alternative energy sources as a substitute for fossil-based fuels (BBM) or reduce the demand for electricity consumption. For the Government itself, renewable fossil-based fuel development program is deemed worthy to be developed and welcomed by foreign countries, especially the developed countries. However, the conversion of supply of non-fossil energy is quite controversial for the Indonesian society. Some of the reasons are it becomes the threat for food resilience and threat to environment (Yoesgiantoro, 2000). When the efforts to develop alternative energy sources is constrained, the steps should be taken by the Government to keep electricity prices affordable for society is allocating electricity subsidies in the state budget every year, especially for class households of R1-900 VA and R1-450 VA. The consequence that arises then is the Government faces to increasing electricity subsidies that becomes a burden for the state budget each year (BKF, 2012). Based on the agreement of the Government and Parliament, in Budget 2016 the amount of the subsidy allocation for electricity has been Rp38, 4 trillion, after reaching a peak in 2012 of Rp103, 3 trillion.

The progress of the electricity subsidy is influenced by several variables, including the exchange rate, ICP, electricity sales growth, shrinkage of the network, the business's operating margin, Base Supply Price (BPP) and the Electricity Rates (TTL). The government will continue to budgeting the electricity subsidy as long as the TTL sets is persistently lower than the electricity BPP plus business operating margin (BKF, 2011). Associated with the efforts to increase the national electrification ratio itself, based on the recommendation of BKF in 2011, it is indicate if in the year 2009, the electrification ratio remained at 64.8\%, then in 2014 it is expected to increase up to $80.3 \%$ with the funding needs of Rp506 trillion. Total funding needs are expected to be met by PT PLN Persero sharing mechanism with the Government amounting to Rp322 trillion and IPP / PPP amounting to Rp184 trillion. By this humongous amount of electricity subsidy, added by the Government's obligation to provide a variety of special subsidies related to the world economic turmoil, which has affected Indonesia, the subsidy burden borne by the Government is hugely inflating. These various subsidy policies are done by considering the level of quality public services (Public Service Obligation / PSO) to the public. Therefore, the thought to begin reducing the subsidy burden is worth to be observed, in particular to the electricity subsidies issues related to the interest of the society (Kadir, 1997).

One discourse worth to consider in order reducing the subsidy burden is market deregulation. According (Ritschel \& Smestad, 2003), mentioned that all over the world, governments are deregulating their electricity 
market to increase competition, lower cost and promote innovation. A states also have to introduced competition in the supply and delivery of electricity, most have elected to continue "public benefits" programs that have traditionally been administered or funded by regulated electric utilities in the areas of energy efficiency, renewable energy and low income assistance (Bolinger, 2001). Government also can implement to divide the burden to the regions, including through the establishment of regional electricity basic tariff. This is deemed as considerable as the participation of regional government in managing the electricity in each region is expected to further increase in future. As the authorities closest to the public, regional governments probably more knowledgeable on the quantity of electricity needs in each region, so it can determine the various electrical policy measures, suitable to the character of respective regions. Related to the regulation in the electricity sector, the Government itself has issued Act No. 30 of 2009 on Electricity. Related to the division of authority, the Government has also enacted Act No. 23 Year 2014 on Regional Government. Based on this regulation of electricity, it is mentioned that the electric power supply is controlled by the state, that its implementation is manage by the Government and the regional government based on the principle of regional autonomy. That means opportunities for independent management of electricity in the region.

Meanwhile based on Act No 23 year 2014 about the Regional Government, electricity has been one of the matters that its authority has been delegated to the regions. It also stated that the Regional Government has authority to set the regional tariff through the regional regulation (Perda). Moreover, the authorities mandatory to be done are composing the regulation to minimize investment cost in the electricity sector, as well as composing regulation for the utilization of energy in an integrated manner. An implication for the electricity authority that has been delegated to the regions is it is mandatory upon the regions to conduct electricity services. However, considering the condition of the regions that has not been possible to organize electricity services independently in all regions. In order to assess the possibility of sharing the burden of the electricity subsidy allocation of central and regional Government further, it is necessary to do a "Study of Potential Electricity Subsidy Sharing by Regional Governments". A few main research questions in this study are including:

- How is the portrait of the division of authority for the electricity management between the central government and regional governments?

- How is the level of readiness of the regional government in the implementation of the electricity subsidy sharing by the regional government, by taking into account its regional financial capability?

As a starting point, in this study the problem constrain and analysis is set already, especially to the readiness of Regional Government by only considering the aspect of APBD funding side and regional economic growth development. The other fundamental aspect such as bureaucracy administration, simple procedure for investment and its permit has not been the main focus. The constrain is also set for the research focus that in the meantime only focused in the merely Regional Government Level. Based on In BKF 2011 subsidy is define as payments made by the government to companies or households to achieve certain goals that make them able to produce or consume a product in larger quantities or at a cheaper price. Economic purpose of subsidies is to reduce prices or increase the output (output). According to (Eng, 2014) a subsidy is a form of government spending that also can be interpreted as a negative tax that will increase their income to receive subsidies or an increase in real incomes if they consume or buy goods that are subsidized by the government with cheap selling prices. Following (Basri \& Munandar, 2009), distinguish two forms of subsidies, whereas subsidies in the form of money (cash transfer) and subsidies in form of goods (in-kind subsidy). The subsidy is a policy aimed at helping specific groups of consumers in order to pay for the products or services received at a rate below the market price, or can also be a policy aimed at helping producers to earn an income above the price paid by the consumer, by providing financing assistance, either directly or indirectly.

In the context of electricity in Indonesia, the electricity subsidy is the amount of funds paid by the Government to PT. PLN Persero calculated based on the difference between the cost of goods sold for low voltage with TDL of year 2001 multiplied by the number of $\mathrm{kWh}$ consumed by customers a maximum of 30 kWh per month. With this subsidy, the expectation is that the availability of electricity can be met, a continuous supply of electricity is stable, as well as providing an opportunity to disadvantaged or poor customers and the community out of reach of service of PT. PLN Persero to be able to enjoy electricity. Electricity subsidies generally have a negative impact, namely the emergence of distortions in the selection of 
alternative energy use. TTL paid by customers are generally below the cost of production (HPP). If the subsidies are removed, the power industry is unattractive to private investors. Therefore, to run the subsidies effectively, the management of the subsidy should consider the following functions:

a) Transparency;

b) Can be formally justified;

c) Focused (the target is clear and direct);

d) It is part of a thorough reform;

e) Timely;

f) Can be rapidly applied; and

g) Non-by passable (no target exemption)

The subsidy itself is generally derived from government. However, in practice, the subsidy can also be derived from the power company, customer, or other party. Subsidies from the government may come from the central government, provincial government, or regency / municipal government. The subsidy comes from the electric company in general is in form of subsidy from the government-owned electricity company to the privately owned electricity company, in order to attract private companies to be willing to invest in the power industry. Subsidies from customers generally in the form of cross-subsidies between customer groups, for instance from industrial customers to residential customers. Meanwhile, subsidies from the other party can be donations, grants, or grants awarded to companies producing electrical energy. When viewed from the side of the user, the subsidy can basically be given to consumers and may also be given to the producers. Subsidies for electricity consumers can be given to disadvantage / poor consumers, for example, consumers with an installed capacity of less than R1-450 VA, where the electricity consumption below the minimum power requirement. Subsidies to consumers may also be given to people in underdeveloped or isolated areas so that they can have electricity. Subsidies to the producers can be granted to private companies willing to build power plants in rural areas, or investment subsidy to the rural electricity network expansion. Subsidies to producers may also be realized in the form of cross-subsidy between the producers, an agreement to buy electricity generated private producers PPA (purchase power agreement), or the ease of investment, such as ease of licensing, import duty exemption for capital goods, as well as tax relief (BKF, 2012).

Funds for the electricity subsidy can be obtained from several sources, including the central government, provincial government, regency / city governments, as well as customers who use excessive power. Funds obtained from customers using excessive power is suitable to cover the subsidies need of the family of power consumers who are economically disadvantaged (Cross-subsidies between customer groups). Regency / city governments concerned for the welfare of its citizens, especially poor people. One effort that can be taken is to help people who are out of reach of electricity network to have affordable electricity network facilities. Therefore, the regency / city governments are appropriately allocate some funds to subsidize the investment in expanding electricity networks in the region. If the financial capacity of the regency / city is not possible to provide subsidy fund investment, the regency / city government can apply for assistance or direction from the provincial government or the central government. Subsidies for the supply of electrical power for the operation of remote areas should be provided by the regency / city, because it is basically regency / municipal governments are oblige to provide facilities needed by the communities, including power facilities. In Table 1, overviews of the types of subsidies that are needed as well as the source of financing of subsidies are given.

Table 1: Consumer Group, Type Subsidies, and Funding Subsidies

\begin{tabular}{|c|c|c|}
\hline $\begin{array}{l}\text { Consumer } \\
\text { Groups }\end{array}$ & $\begin{array}{l}\text { Appropriate } \\
\text { subsidies to give }\end{array}$ & Source of Financing of Subsidy \\
\hline $\begin{array}{l}\text { Household } \\
\text { without electricity } \\
\text { supply }\end{array}$ & Investment Subsidy & $\begin{array}{l}\text { the regency / city governments } \\
\text { the provincial government } \\
\text { the central government }\end{array}$ \\
\hline $\begin{array}{l}\text { Household } \\
\text { without electricity } \\
\text { supply }\end{array}$ & Operation Subsidy & the regency / city governments \\
\hline $\begin{array}{l}\text { Disadvantage } \\
\text { household }\end{array}$ & Focused Subsidy & Excessive household \\
\hline
\end{tabular}




\begin{tabular}{lll}
\hline $\begin{array}{l}\text { Disadvantage } \\
\text { household } \\
\text { Excessive }\end{array}$ & No Subsidy & - \\
household & No Subsidy & - \\
\hline
\end{tabular}

Source: Handoko \& Patriadi (2006)

\section{Methodology}

In general, the type of research used in this study is the kind of explanatory research that aims to answer whether a particular social phenomenon associated with other social phenomena or a variable is related to other variables. In this case the social phenomena or variables to be analysed is a social phenomenon of the persistently arising electricity subsidy due to higher demand for electricity actual that associated with the potential for sharing electricity subsidies by Regional Governments. In this method of analysis, this study will use qualitative descriptive approach through the analysis of the division of authorities of electricity sector between the central government, provincial and regency / city, analysis of potential funding Budgets of Regional Government at the provincial level that is manifested from the indicators of Fiscal Capacity of Regions, as well as indicators of economic growth development in the region that are presented in tables, pictures and graphics. In order to have a comprehensive analysis. To get the data and information required in this study it used secondary data obtained through the collection of data / information such as documents, reports and the results of other studies that have been published by some of the authorized agencies including the Directorate General of Fiscal Balance, Ministry of Finance, PT. PLN Persero and also BPS (Statistic Agency).

\section{Result and Discussion}

The Juridical Analysis: In accordance with the Act No. 23 Year 2014 regarding Regional Government, government affairs division consists of absolute government affairs, concurrent government affairs, and public government affairs. Absolute government affairs are the government functions that are still fully under the authority of the Central Government. Functions which still lies within the competence of the Central Government including defence and security affairs, military, judicial, religious, fiscal, and monetary and foreign policy. Meanwhile the concurrent government affairs are the government affairs that are shared between the central government and the province and regencies / cities. Concurrent administration affairs are submitted to the Region later became the basis of the implementation of the principle of regional autonomy. The general government affairs are the government affairs under the authority of the President as head of government. The Regulation also regulates the issue of distribution of governmental affairs remain as authority of the Central Government as well as functions that has been delegated to the provincial government, regency and city. Furthermore, the division of government functions that fully become an authority of Government and government functions that are shared between level and / or structure of government is divided as obligatory or optional matter. The type of obligatory matter shall mean the regional government through funding from the budget shall conduct these functions, considering its characteristic that is a basic services and government matter unrelated with basic services.

Some types of obligatory functions related to basic services as referred earlier are including education, health, public works and spatial planning, housing and residential areas, peace, public order, and community and social protection. While the obligatory government functions that is not related to basic services are including: employment, empowerment of women and protection of children, food, land, environment, population administration and civil registration, community and village empowerment, population control and family planning, transportation, communications and informatics, cooperatives, small businesses, and medium enterprises, investment, youth and sports, statistics, coding, culture, libraries and archives. In the other side, the optional functions implies that this functions are the selection at each regions that hold it, and has nothing to do with the function of basic public services. The Government optional functions that based on Act Number 23 Year 2014 are including marine and fisheries, tourism, agriculture, forestry, energy and mineral resources, trade, industry and transmigration. In these functions of energy and mineral resources are subdivided into the functions of geology, mineral and coal, oil and gas, renewable energy and electricity. Thus, it can be seen that the electricity sector is an optional functions in the region, inside of the category of 
function of energy and mineral resources. By classifying into the optional functions, thus the electricity sector is still become the main authority of the central government for its generation. Meanwhile the regions help in accordance to their fiscal capacity. However, the electricity matters division of authority between the central government, provincial government and regency / city is based on Act Number 23 Year 2014 on Regional Government are as follows:

\section{Table 2: Division of Authority of Sub Electricity}

The determination of business area of electricity
generation and trade permit of electricity across
countries

Provincial Government

The issuance of electricity generation business of non-SOE and selling of electricity or leasing of distribution network to electricity provider within the province.

The issuance of business permits of electricity generation across province, SOEs and selling of electricity or leasing of distribution network to electricity provider across the province or SOEs.

The issuance of permit of operation that its installation facility is covering the area across province, or within the area above 12 Miles of sea

The electricity tariff determination for consumer and issuance of usage permit of telecommunication network, multimedia, and informatics from the permit holders determined by the Central Government.

The agreement of electricity selling price and network rent, electricity generation business planning, selling of excessive electricity from the permit holder determined by the Central Government.

The issuance of business permit of electricity supporting service for the foreign investor /majority of shares hold by the foreign investor.

The issuance of permit of operation that the installation facility is located within the province.

The electricity tariff determination for consumer and issuance of usage permit of telecommunication network, multimedia, and informatics from the permit holders determined by the Provincial Government.

The agreement of electricity selling price and network rent, electricity generation business planning, selling of excessive electricity from the permit holder determined by the Provincial Government.

The issuance of business permits of electricity supporting service for the regional enterprise/majority of shares hold by the regional investor.

Provision of funds for the underprivileged groups, development of power supply facilities underdeveloped, remote areas and rural areas.

Provision of funds for the underprivileged groups, development of power supply facilities underdeveloped, remote areas and rural areas.

Source: Law Number 23 Year 2014

Based on Table 2 regarding the division of authority of sub electricity matters then it can be analysed that the role of central government and Provincial Government is more dominant and quite central, regarding the issuance of permit of electricity development business in the central or regional levels. However, based in this regulation the regency or cities government is not having enough authority in the undertaking of electricity business. This is based on the consideration that electricity sector is having an impact that has across territorial, thus the coordination under provincial Government control is needed. This finding is supporting the initial hypothesis of selection of province as a sample on this study of potential of electricity subsidy sharing at the region itself. The next juridical basis to be analysed is the Act No. 30 Year 2009 on Electricity. In this Act, stated that the implementation of electricity generation business by the Central Government and Regional Government is conducted by the state owned enterprise (BUMN) and regional state owned enterprise (BUMD). Under Act No. 30 of 2009, the central government authority in the electricity sector 
include: a) determining the national electricity policy; b) the determination of the legislation in the electricity sector; c) establishment of guidelines, standards and criteria in the field of electricity; d) establishment of guidelines for the determination of electricity tariff for consumers; e) determination of the general plan of the national electricity; f) determination of the business area; g) the determination of electricity trading crosscountry; h) determination of the electricity generation business license for the enterprise that its business area are across the province, conducted by the state-owned enterprises and selling of electricity and / or leasing of electric power network to the license holder of electricity generation business established by the Government.

Moreover, the Central Government is also in charge in the matter of operational permit determination that its installation facility is covering across provinces area, determination of electricity tariff for the consumers of the holder of electricity generation business established by the Government, the determination of the approval of the selling price of electricity and rents of electric power networks of license holders of electricity generation set by the Government, the determination of the approval of the sale of excess electricity from the holder of an operating license set by the Government, issue permits of electricity supporting business services conducted by state-owned enterprises or foreign investors / which its shares are owned by foreign investors in majority. It is also including that the Central Government is still obliged to establish permit utilization of the electric power grid for the benefit of telecommunications, multimedia, and information on the network belonging to the holder of electricity generation business or operations set by the Government, guidance and supervision to business entities in the electricity sector whose licenses are set by the government, the appointment of electricity inspectors, guidance to electricity inspector functional to all levels of government and the establishment of administrative sanctions to entities whose licenses are set by the government.

In compliance with Act No. 23 of 2014 on Regional Government, Act No. 30 Year 2009 on Electricity also governs the authority of the Provincial Government including: the establishment of provincial regulations in the electricity sector, the establishment of the general plan of electrification of the provinces, issue permits electricity generation business for enterprises with cross-regency/city business area, determination of operation permits which its installation facilities are covering cross-regency/city and the determination of electricity tariff for consumers of license holders of electricity generation set by the provincial government. In the other side, the Provincial Government also stipulates the approval of electricity selling price and rent of electricity network for business entities that sell electricity and or lease the electricity network to entities whose licenses are set by the provincial government, the establishment of the approval of the sale of excess electricity from holders of operating licenses set by provincial governments, issue permits utilization of the electric power grid for the benefit of telecommunications, multimedia, information on the networks of license holders electricity generation or permit of the operation set by the provincial government, guidance and supervision to business entities in the electricity sector whose licenses are set by the provincial government, appointment of inspectors electricity for the province as well as the determination of administrative sanctions to entities whose licenses are set by the provincial government.

The interest thing on the Act No.30 Year 2009 is it is also regulating the issue of authority of sub electricity matter in the area of regency/city Governments. Several things that become the authority of the regency/city government are including the establishment of a general plan electricity area of regency and city, issue permits of electricity generation business to a business entity which its business area are in the regency / city, establishment operating permit installation facilities in the regency / city, determination of electricity tariff to consumers from license holders of electricity generation business set by the regency / city government. In addition they also stipulate the approval electricity selling price and rental of electricity network for business entities that sell electricity and / or lease electricity network to entities whose licenses are set by the regency / city, the establishment of a business license supporting service electric power for enterprises whose majority owned by domestic investors, the establishment approval from the sale of excess electricity from operating license holders whose licenses are set by the regency / city government. The distinction of Act No. 23 of 2014 is the regulation on the authority of the Government of Regency / City in the management of the electricity sector. Some of these are the determination of permits of utilization of electric power network for the benefit of telecommunications, multimedia, and informatics in the networks of license holders electricity generation or license of operation sets by the regency / city government, guidance and 
supervision to business entities in the electricity sector whose license is granted by the regency / city government, the appointment of inspectors electricity to the regency / city as well as the determination of administrative sanctions to entities whose license is granted by regency / city government.

On the regulation of Act No. 30 of 2009 is reinforced by a Government Regulation (PP) No. 14 of 2012 on Electricity Generation Business activities particularly related to licensing of electricity generation business and tariffs. In article 10, paragraph 2 states that permit of electricity generation business given by the Minister for enterprises that its business are covering area across the provinces, conducted by state-owned enterprise and selling electricity and / or leasing of electric power network to the license holder of electricity generation business for whose license is granted by the Minister. Meanwhile the governor grant a business license approval for business entities that its business area are across regency / cities and sell electricity and / or lease electric power network to the license holder of electricity generation business which its permit is granted by the Governor. For the Regent / Mayor can give approval to the license to a business entity that its business area in the regency / city and sell electricity and / or lease electric power network to the license holder of electricity generation business whose license is granted by the regent / mayor.

In chapter 41 also mentioned that the electricity tariff for consumers determined by the Minister after obtaining the approval of the House of Representatives (DPR), in terms of electric power supplied by the electricity generation business whose licenses are set by the Minister. For the governor, after obtaining the approval of the Regional Representatives Council (DPRD), in terms of electric power supplied by the electricity generation business whose license is granted by the governor and regent / mayor after obtaining the approval of Parliament, in terms of electric power supplied by the electricity supply generation whose license is granted by the regent / mayor. From some of these explanations, it can be concluded that the authority of the electricity sector has been delegated to the regions through the division of affairs between the central government, provincial government and regency / city especially in the issuance of business licenses and tariffs. This is strong supports for the electrical subsidy plan of fund sharing between the Central Government and the Regions. However, to think that electricity is still an optional function for the regions, thus the central government funding remains a major driving force with the support of the regional budget (APBD) based on fiscal capacity of each region.

Regional Financial Analysis: Based on the analysis of juridical factors, it is known that electricity is categorized as optional function for the regions. Therefore, there is no obligation for the region to allocate the regional budget plan to manage the electricity matter in respective region. In the other side, this condition is requiring an obligation of central Government to allocate a portion in State Budget Plan (APBN) in the guidance and supervision of electricity in the region. However, Due to the characteristic of electricity that is basic needs and inter-territorial and considering the huge burden borne by the state budget (APBN) each year, thus the role of region is highly expected to accelerate the development. Obviously, by adjusting it with the financial condition of regional budget in each region. The readiness of each region budget then calculated based on Regional Fiscal Capacity Indicator. The Government itself each year is having a counting mechanism of Regional Fiscal Capacity, which is ratified through Regulation of Finance Minister (PMK). Based on PMK No. 33/PMK 07/2015 regarding Regional Fiscal Capacity Mapping, the meaning of Regional Fiscal Capacity that afterward called Fiscal Capacity is a representation of financial strength of each region, that reflected through the general income of Regional Budget (APBD) (excluding special allocation fund, emergency fund, and long term loan fund, and other income which its usage is focused only for funding specific expenditure) to fund the government duty after reduced by personnel expenditure and associated with the number of the poor.

The Regional Fiscal capacity then is enable for proposing the Regional Government as a recipient of grant, the valuation of proposal of regional loan, the determination of supporting fund amount, if required and/or other thing that regulated specifically on the provision of the law. The Regional Fiscal Capacity is consist of Provincial Fiscal Capacity Map and Regency/City Fiscal Capacity Map. In this study, for the initial analysis of Regional Fiscal Capacity used is Provincial Region Fiscal Capacity. Based on Table 3, it shows that several regions have Regional Fiscal Capacity classified as very high category, which are DKI Jakarta Province, East Kalimantan Province, West Papua Province, and North Kalimantan Province. If in the future the Central Government willing to share the electricity subsidy burden with several regions, these regions are appropriate to be the main priority. Interestingly, the regions that included in the very high Regional Fiscal 
Capacity status are having different characteristics. DKI Jakarta as the state capital is known as a rich region as the basis of tax revenues and levies. Meanwhile, the province of East Kalimantan, Papua, West and North Kalimantan is known as a region rich in natural resources (SDA). If the probability wants to be broaden, several regions that include in the high category of Regional Fiscal Capacity that are worth to recommend are NAD Province, Central and South Kalimantan, Bali, North Maluku and Riau Archipelago. Coincidentally, these high category status' regions are regions with abundance of natural resource (SDA), that later potentially be used as alternative electricity generation, either non-renewable fossil-based fuel (BBM) basis or the renewable one.

Table 3: Provincial Region Fiscal Policy

\begin{tabular}{|c|c|c|c|}
\hline No & Region & Fiscal Capacity Index & Category \\
\hline 1 & NAD & 1,15 & High \\
\hline 2 & North Sumatra & 0,37 & Low \\
\hline 3 & West Sumatra & 0,49 & Low \\
\hline 4 & Riau & 0,99 & Medium \\
\hline 5 & Jambi & 0,65 & Medium \\
\hline 6 & South Sumatra & 0,34 & Low \\
\hline 7 & Bengkulu & 0,37 & Low \\
\hline 8 & Lampung & 0,24 & Low \\
\hline 9 & DKI Jakarta & 8,69 & Very High \\
\hline 10 & West Java & 0,27 & Low \\
\hline 11 & Central Java & 0,12 & Low \\
\hline 12 & DIY & 0,26 & Low \\
\hline 13 & East Java & 0,20 & Low \\
\hline 14 & West Kalimantan & 0,42 & Low \\
\hline 15 & Central Kalimantan & 1,35 & High \\
\hline 16 & South Kalimantan & 1,50 & High \\
\hline 17 & East Kalimantan & 3,66 & Very High \\
\hline 18 & North Sulawesi & 0,66 & Medium \\
\hline 19 & Central Sulawesi & 0,34 & Low \\
\hline 20 & South Sulawesi & 0,32 & Low \\
\hline 21 & Southeast Sulawesi & 0,35 & Low \\
\hline 22 & Bali & 1,49 & High \\
\hline 23 & NTB & 0,15 & Low \\
\hline 24 & NTT & 0,12 & Low \\
\hline 25 & Maluku & 0,30 & Low \\
\hline 26 & Papua & 0,95 & Medium \\
\hline 27 & North Maluku & 1,15 & High \\
\hline 28 & Banten & 0,58 & Medium \\
\hline 29 & Babel & 1,27 & High \\
\hline 30 & Gorontalo & 0,33 & Low \\
\hline 31 & Kepri & 1,68 & High \\
\hline 32 & Papua Barat & 2,45 & Very High \\
\hline 33 & East Sulawesi & 0,47 & Low \\
\hline 34 & North Kalimantan & 3,66 & Very High \\
\hline
\end{tabular}

Source; MOF Regulation No. 33 Year 2015 
Regional Economic Analysis: In the economic growth analysis, the data used is the data of economic growth progress from the year of 2008 until year of 2012. This regional economic is very important to be used as one of consideration aspects of selection of priority region that has potential of electricity subsidy sharing in the region, considering the main role of electricity to boost the economic growth. The regions having appropriateness of electricity level surely will become the favorite regions for various incoming investments, which in turn will grow the invested region economy. In contrary, regions with insufficient appropriateness for electricity level definitely will become the main hindrance of incoming investment in the region. Whenever the regional investment has grown vastly, along with its economic growth, the electricity enhancement effort is also not a difficult task to do. The private sector of electricity development will race against each other to invest their capital, if only the modality has happened, without forgoing several supporting factor such as certainty of law, bureaucratic administration and licensing facilities in addition to regional policies regarding labor. Based on Table 4, regarding the development of regional economic growth from 2008 to 2012, there are some interesting findings when compared with the analysis related to Table 3 of Regional Fiscal Capacity. If we refer to Table 3, then some of the priority areas of potential sharing of electricity subsidies by the regional government are DKI Jakarta, East Kalimantan, West Papua and North Kalimantan Province. When analysed by looking at the development of regional economic growth in Table 4, the area that has the most rapid economic growth from 2008 to 2012 is West Papua province with an average economic growth of around $23.28 \%$ compared to Jakarta by $7.75 \%$ and East Kalimantan by $5.08 \%$. While North Kalimantan province have not been included in the calculation of the BPS as a new province of the results of regional expansion.

Table 4: Development of Regional Eco. Growth

\begin{tabular}{llllll}
\hline Region & $\mathbf{2 0 0 8}$ & $\mathbf{2 0 0 9}$ & $\mathbf{2 0 1 0}$ & $\mathbf{2 0 1 1}$ & $\mathbf{2 0 1 2}$ \\
\hline NAD & $-5,24$ & $-5,51$ & 2,74 & 5,09 & 5,21 \\
North Sumatra & 6,39 & 5,07 & 6,42 & 6,63 & 6,22 \\
East Sumatra & 6,88 & 4,28 & 5,94 & 6,25 & 6,35 \\
Riau & 5,65 & 2,97 & 4,21 & 5,04 & 3,55 \\
Jambi & 7,17 & 6,39 & 7,35 & 8,54 & 7,44 \\
South Sumatra & 5,07 & 4,11 & 5,63 & 6,50 & 6,01 \\
Bengkulu & 5,75 & 5,62 & 6,11 & 6,45 & 6,60 \\
Lampung & 5,53 & 5,26 & 5,89 & 6,43 & 6,48 \\
DKI Jakarta & 6,23 & 5,02 & 6,50 & 6,73 & 6,53 \\
West Java & 6,21 & 4,19 & 6,20 & 6,48 & 6,21 \\
Central Java & 5,61 & 5,14 & 5,84 & 6,03 & 6,34 \\
DIY & 5,03 & 4,43 & 4,88 & 5,17 & 5,32 \\
East Java & 6,16 & 5,01 & 6,68 & 7,22 & 7,27 \\
West Kalimantan & 4,49 & 4,80 & 5,47 & 5,96 & 5,84 \\
Central Kalimantan & 6,17 & 5,57 & 6,50 & 6,76 & 6,68 \\
South Kalimantan & 6,45 & 5,29 & 5,59 & 6,12 & 5,73 \\
East Kalimantan & 4,90 & 2,28 & 5,10 & 4,08 & 3,98 \\
North Sulawesi & 10,86 & 7,85 & 7,15 & 7,39 & 7,86 \\
Central Sulawesi & 7,77 & 9,89 & 8,74 & 9,15 & 9,26 \\
South Sulawesi & 7,78 & 6,23 & 8,19 & 7,62 & 8,37 \\
Southeast Sulawesi & 7,28 & 7,57 & 8,22 & 8,96 & 10,41 \\
Bali & 5,98 & 9,60 & 5,83 & 6,50 & 6,65 \\
NTB & 2,83 & 12,13 & 6,35 & $-3,15$ & $-1,13$ \\
NTT & 4,84 & 4,30 & 5,25 & 5,63 & 5,43 \\
\hline
\end{tabular}




\begin{tabular}{llllll}
\hline Maluku & 4,23 & 5,44 & 6,46 & 6,07 & 7,81 \\
Papua & $-1,40$ & 22,22 & $-3,19$ & $-5,32$ & 1,08 \\
North Maluku & 5,99 & 6,07 & 7,97 & 6,39 & 6,66 \\
Banten & 5,77 & 21,29 & 6,11 & 6,39 & 6,15 \\
Babel & 4,60 & 3,74 & 5,99 & 6,46 & 5,72 \\
Gorontalo & 7,77 & 7,54 & 7,60 & 7,68 & 7,74 \\
Kepri & 6,63 & 3,52 & 7,19 & 6,66 & 8,21 \\
Papua Barat & 7,85 & 13,86 & 28,46 & 27,08 & 15,85 \\
West Sulawesi & 12,09 & 6,00 & 11,91 & 10,31 & 9,00 \\
\hline
\end{tabular}

Source: BPS, 2014

If the analysis is extended to regions with high category of fiscal it is consisting of NAD, Central and South Kalimantan, Bali, North Maluku and Riau Archipelagos, thus the recommended regions are only the North Maluku province with an average economic growth rate of $8.27 \%$ of in 2008 and 2012, and the Riau Archipelagos Province with an average economic growth rate of $8.05 \%$. The interesting thing can be seen in the case of the NAD province. Based on Table 4, NAD Province had contracted economic growth to minus $5.24 \%$ and $5.51 \%$ in 2008 and 2009 . These conditions would obviously not be a positive thing in supporting economic development in the area, unless it was caused by external events such as natural disasters or other force majeure. NAD province itself had been affected by the tsunami in 2004. Other regions experiencing economic growth, which is quite attractive, are the province of North Sulawesi with economic growth on average by $10.28 \%$, the province of Central Sulawesi of $11.20 \%$, the Province of Southeast Sulawesi $10.61 \%$, Province of West Sulawesi with an average growth of $12.3 \%$, and $11.43 \%$ growth of Banten Province.

\section{Conclusion}

As a final note, based on the result of study of potential sharing of electricity subsidy by the Regional Government, we can conclude that electricity sector has a very important role in the process of development for the society welfare enhancement. Therefore, the electric power has become a source of energy that is vital for the daily household life, industrial activities, especially small and medium enterprises (SMEs) as well as other commercial activities. Unfortunately, most of the electricity generation activities are heavily dependent to the supply of fossil-based fuel. Therefore, the dependency over fossil-based fuel as the supply of electricity generation should be minimized to the optimal level, either from the demand side or from the development of alternative of power supply, which has renewable characteristic. When the efforts to develop alternative energy sources is constrained, the steps should be taken by the Government to keep electricity prices affordable for society is allocating electricity subsidies in the state budget every year, especially for class households of R1-900 VA and R1-450 VA. The consequences that arises is the Government faces to increasing electricity subsidies that becomes a burden for the state budget each year, that is why the Government shall thinking about availability of an alternative of sharing the electricity subsidy funding with the Regional Government.

By using the juridical analysis, it can be concluded that the authority of the electricity sector has been delegated to the regions through the division of affairs between the central government, provincial government and regency / city especially in the issuance of business licenses and tariffs. This is strong supports for the electrical subsidy plan of fund sharing between the Central Government and the Regions. However, to think that electricity is still an optional function for the regions, thus the central government funding remains a major driving force with the support of the regional budget (APBD) based on fiscal capacity of each region. Based on the analysis of Regional Fiscal Capacity, DKI Jakarta Province, East Kalimantan Province, West Papua Province and North Kalimantan Province are the regions that deserve to be a top priority. Some areas that included into the category of high Regional Fiscal Capacity also deserve to be recommended are NAD, Central and South Kalimantan, Bali, North Maluku and Riau Archipelagos. In contrary, if the analysis of the development of regional economic growth is used, the area that has the most rapid economic growth from 2008 to 2012 is West Papua province with an average economic growth of 
around $23.28 \%$ compared to Jakarta by $7.75 \%$ and East Kalimantan by $5.08 \%$. The other recommended regions are the province of North Sulawesi with economic growth on average by $10.28 \%$, the province of Central Sulawesi of $11.20 \%$, the Province of Southeast Sulawesi $10.61 \%$, Province of West Sulawesi with an average growth of $12.3 \%$, and $11.43 \%$ growth of Banten Province

The policy recommendation result from this study is the acknowledgement of the need of fund allocation for electricity development by the Central Government either through the State Budget (APBN) or through other funding scheme, considering the fact that the authority of electricity characteristic in the region is still classifies as optional functions. However, the plan for having sharing of funding of electricity subsidies is worth to be implemented, especially for several regions that has Regional Fiscal Capacity categorized as high and very high. If the plan of sharing of funding implemented, the Central Government shall promptly prepares all of the regulation and supporting mechanism, to implement the policy optimally. For several regions classified as appropriate criteria to perform the sharing of funding of electricity subsidies should mandatorily obtain a reward for its performance through grant of compensation of obtaining priority for infrastructure development either the one directly related with electricity or development of other sectors of economy. This thing onward could create positive boost for the other regions, to compete for enhancing their Regional Fiscal Capacity, to perform their electricity mechanism independently.

\section{References}

Ahlborg, H. (2015). Provision of electricity to African household: The importance of democracy and institutional quality. Energy Policy, 87, 125-135.

Bappenas. (2011). Evaluasi Pembangunan Perdesaan Dalam Konteks Peningkatan Kesejahteraan Masyarakat. Final Report. Jakarta

Basri, F. \& Munandar, H. (2009). Lanskap Ekonomi Indonesia. Jakarta: Kencana Prenada Media Group;

BKF. (2008). Pemantauan Efektivitas dan Efisiensi Kebijakan Subsidi. Jakarta.

BKF. (2011). Kajian Evaluasi Implementasi Roadmap Subsidi BBM dan Subsidi Listrik Jangka Menengah. Jakarta.

BKF. (2012). Kajian Desain Subsidi Tepat Sasaran. Jakarta

Bolinger, M. (2001). States Emerge as Clean Energy Investors: A Review of State Support for Renewable Energy. The Electricity Journal, 1, 1040-6190l.

Eng, P. V. D. (2014). Mining and Indonesia's Economy: Institutions and Value Adding .Japan: Hitotsubhasi University.

Hadi, D. P. (2015). Strategi Pemberdayaan Masyarakat Pada Usaha Kecil dan Menengah Berbasis Sumber Daya Lokal Dalam Rangka MDGs 2015 (Studi Kasus PNPM-MP Kabupaten Kendal). Jurnal Ilmiah CIVIS, 5(1).

Haryanto, J. T. \& Purwanta, W. (2014). Deteksi Dini Perilaku Krisis Listrik di Indonesia. Yogyakarta: Diandra Creative Publisher.

Handoko, R. \& Patriadi, P. (2006). Evaluasi Kebijakan Subsidi Non-BBM. Jurnal Kajian Ekonomi dan Keuangan, $9(4)$.

Kadir, A. (1997). Pembangkit Tenaga Listrik. Jakarta: Universitas Indonesia Publisher.

Law Number 23 Year 2014 on Local Government. 2014.

Ministry of Finance Regulation No. 33 Year 2015 about Map of Local Fiscal Capacity

Ritschel, A. \& Smestad, G. P. (2003). Energy subsidies in California's electricity market deregulation. Energy Policy, 31, 1379-1391.

Yoesgiantoro, P. (2000). Ekonomi Energ: Teori dan Praktik. Jakarta: LP\#ES. 